\title{
Jute: Solution to Global Challenges and Opportunities of Bangladesh
}

\author{
Ahnaf Chowdhury Niloy (iD $\square^{1}$ \\ Department of Business Administration, East West University, Dhaka, Bangladesh ${ }^{1}$
}

\begin{abstract}
Purpose- The purpose of this paper is to identify possible diversifications of jute to create more sustainable businesses for economic development.

Design/Methodology-The paper is prepared using secondary sources of data including published journals, data from research database, news, periodicals, books and websites. The paper is prepared in an exploratory manner, describes several data through graphical representations, and is focused on Bangladesh only.

Findings- The study finds that jute's economic and ecological benefit can make it a cash cow for Bangladesh. Its immense ability of diversification makes it a sustainable solution.

Practical Implications- The study shows the feasibility of the project from a government perspective. The study can be practically applicable at economic scale that can be highly beneficial for jute producing countries like Bangladesh.
\end{abstract}

$\triangle$ Corresponding author: ahnafniloy@outlook.com

\section{ARTICLE INFO}

Received: April 15, 2021

Revised: April 28 \& May 11, 2021

Accepted: May 11, 2021

Published: May 12, 2021

\section{Keywords:}

Bangladesh

Bioplastic

Diversification

Jute

Sustainability

(cc) BY (C) 2021 The Author(s)

\section{Introduction}

Before 1980, jute was known as "The Golden Crop" of Bangladesh due to its immense contribution in the export market. Though India has more production of jute compared to Bangladesh, but the better quality of jute was always an advantage for Bangladesh that made it a monopolistic market due to its contribution in exports of around 80\% in 1947-48 that within 1975-76, declined to just 25\% (Banglapedia, 2015). In 2018 it was reported that Bangladesh produced around 1/3 of world's total jute production (Islam R., 2018). Compared to other industries that exist in Bangladesh, jute has a very prominent future that sadly the government is unable to use properly. In Bangladesh, currently the major export sector is ready-made garments (RMG) which contributes to around $84.21 \%$ of the total with 4621 factories, 4.1 million workers and exports worth 40535.04 Million USD (BGMEA, 2020). Though RMG is the backbone of Bangladesh's exports currently, it is also a drawback for its economy as Bangladesh is highly dependent on this one particular sector. Thus diversifying the exports is highly required to minimize risk in extreme situations. Bangladesh's jute industry had a labor force of 250,000 people earlier but now only 50,000 people work in its production (Al Jazeera, 2008). The major drawback Bangladesh faces in most industries is the lack of raw materials and skilled workforce. Starting from 
RMG, steel, electronics to pharmaceuticals - a big portion of its raw materials are imported. Thus, even though the country provides cheap labor it gets a significantly lower marginal profit. Jute, which is highly being ignored, can play a vital role as it is not produced in most countries because of the required weather and environment for producing it. It can be mostly produced in the Indian subcontinent area as geographically this is the ideal place for its production. Though it has been declining in years, the jute business is widely dominated by Bangladesh with 1.6 Million tons of production making it the 2nd largest producer of the cash crop (Indexbox, 2020).

\section{Methodology}

The paper was prepared in an exploratory and descriptive manner. Secondary data from a number of sources have been used to justify the argument. The sources used are- books, published journal articles, websites, newspaper, and thesis. Data for figures have been collected from Marketline Research Database and Global Data Research Database. The unstructured data have gone through data cleaning process and showcased in a graphical manner for better understanding. Adopted information which are unchanged and used directly from the source have been properly cited. Most data files have been analyzed using Google Sheets and IBM SPSS. Graphical presentations of figures include several forms of bar diagrams. All the information used are cited properly and attached at the end of the paper.

\section{Findings}

The study identifies that jute is a major element in sustainable development and a fighting tool against climate change. Mentioned in a later paragraph, jute has high ability of air purification that is very much essential for countries like Bangladesh and India whose air quality is significantly poor. Apart from the ecological benefit, jute also possess high level of economic advantages. Starting from stick to its leaf, jute is 100\% biodegradable and has immense opportunities to be diversified into several industries.

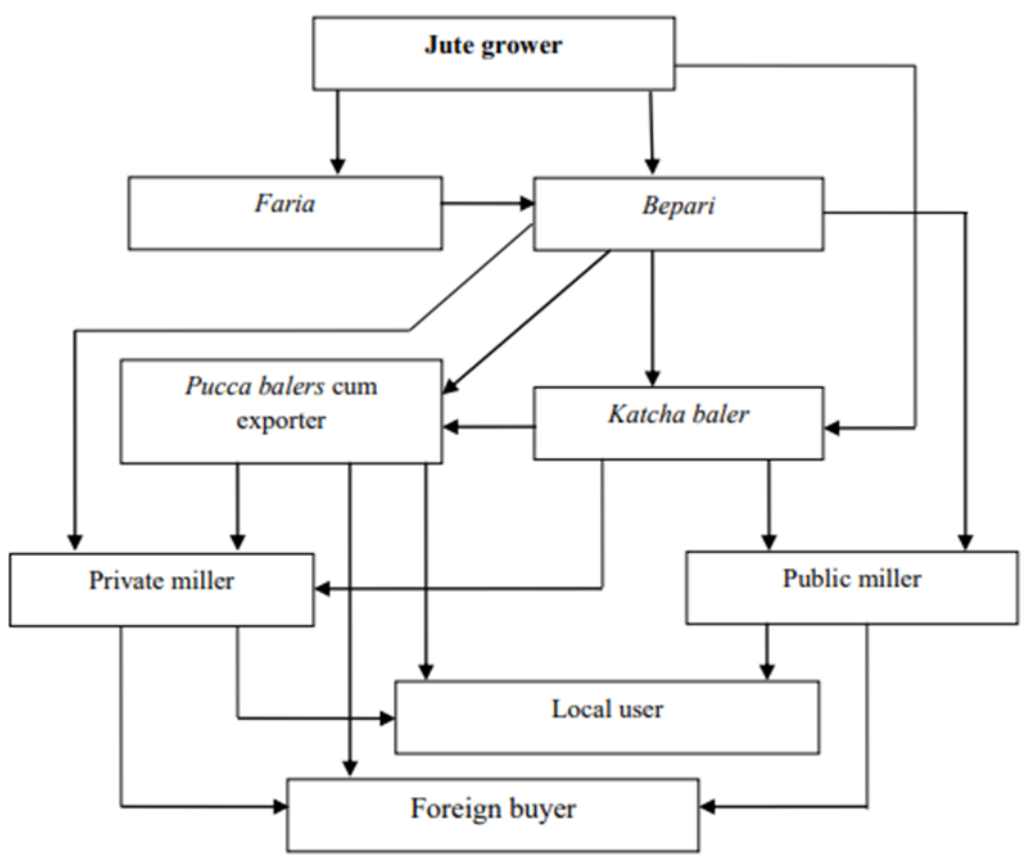

Figure 1. Marketing Channel of Jute in Bangladesh

Its every element can be usable as a raw material for a number of industries such as - leaf in tea industry, stick in charcoal and makeup industry, cellulose in viscose, textile, bioplastic industry, fiber in automobile 
industry and so on. The economic benefit is so high that, jute alone has the ability to be a major cash cow for export earnings of Bangladesh and India. With high demand for sustainable and biodegradable products, a number of products made of jute can create a blue ocean in the marketplace, such as jute based biopolymer both cost friendly and more eco-friendly. Some products can be used as a natural fiber composite (NFC) and be a cost reducer, such as jute based viscose and jute-cotton (50:50) jeans. The issue that jute industry faces in terms of Bangladesh, is the lack of governmental support and intermediary influences. The sophisticated supply chain has made jute a less profitable production option for the producers that has led to a dramatic drop in production of jute over the years.

\section{Historical Background and Climate Action}

\section{Export Contribution of Bangladesh}

Balance of trade has been a long term issue of Bangladesh. Trade liberalization has been one of the major policy reforms that the country has taken in years. Bangladesh is one of the founding members of WTO and in the early 1990's it has taken a lot of trade liberalization programs (Moniruzzaman, 2010). RMG made a drastic change in the exports of Bangladesh after the 80's. In terms of total exports, RMG and Knitwear's share that increased only 1\% in 1981 moved up to $40 \%$ by 1990 and about $76 \%$ by 2000 (Moniruzzaman, 2010). About 18.84\% decline was recorded in Bangladesh's RMG in the fiscal year 2019-20 that has a value of USD 27.7 Billion (Munni, 2020a). With a 10.55\% growth rate, Bangladesh's RMG contributed about $84.21 \%$ in terms of exports worth USD 40.53 billion in fiscal year 2018-19 (Ishaque, 2019). Jute was a major export back in 1972-73 that contributed to around $90.7 \%$ of total exports and declined to $66.2 \%$ in 1981-82 (Moniruzzaman, 2010). According to the World Trade Statistical Review 2020, Bangladesh had a global market share in apparel exports of $6.8 \%$ in 2019 that increased from $6.4 \%$ in 2018 and the total market size fell to $\$ 411$ billion from \$421 billion in 2019 (Ovi, 2020). In the global pandemic of coronavirus where all industries have faced severe crisis, Jute has grown 14\% year on year to USD 791 million in the July-April period of 2020 and also beat the target of $17 \%$ where all other sectors slumped and faced negative figures (Harmachi, 2020).

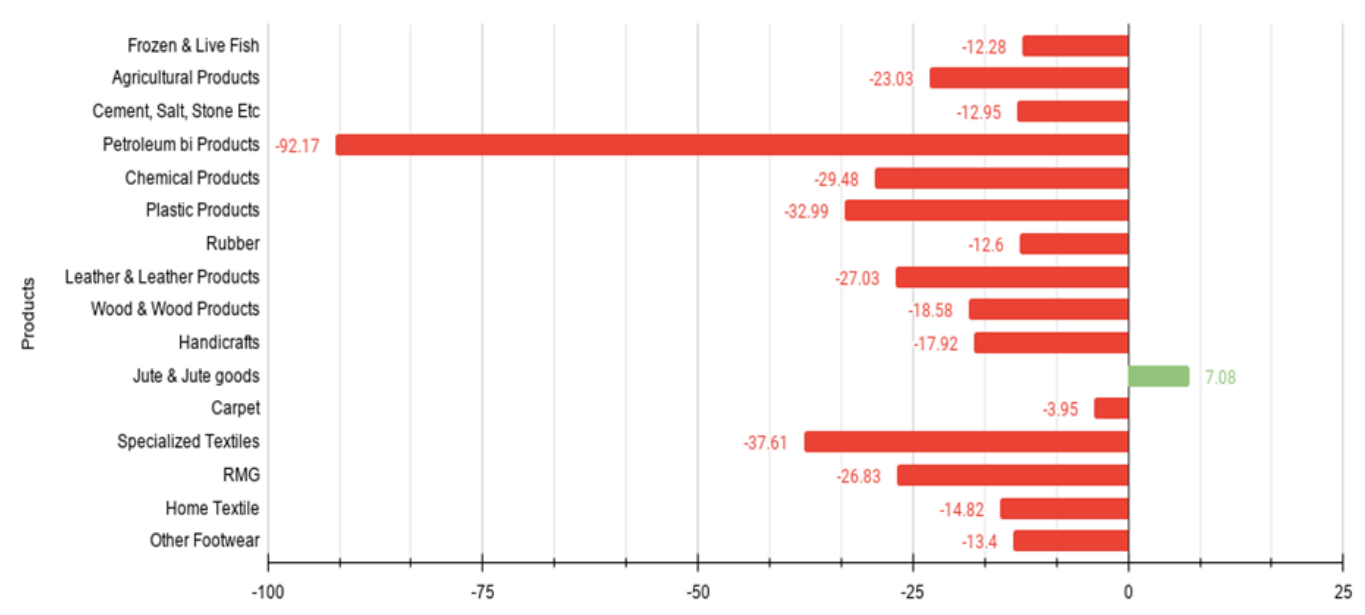

Figure 2. Percentage of export performance of Goods for fiscal year 2019-20 July-June, Bangladesh

Bangladesh has an existing global market share of $24.6 \%$ in terms of export of Jute, making Bangladesh the 2nd highest exporter of this good (SME Foundation, 2015). The jute sector overtook leather's position in Bangladesh's overall export in FY 2019-20 (Bay, 2020).

\section{The Global Plastic Problem}


Around the world, one million plastic drinking bottles are purchased every minute, while up to 5 trillion single-use plastic bags are used worldwide every year (UN Environment, 2018). As the world is highly dependent on plastic for lower cost, finding the proper solution isn't that easy. Any producer would definitely want to reduce cost. Thus, plastic is the solution they find for packaging. It is estimated that a foam plastic cup, a plastic beverage holder, a disposable nappy and a fishing line takes 50 years, 400 years, 450 years, and 600 years to decompose accordingly (Guern, 2019). Plastic is an everyday element of our life and also a long term problem. It is not only the problem of the land, but also the ocean. An estimated 8 million tons of plastics are thrown into the ocean every year (Boucher \& Friot, 2017). 2 years ago, a British diver took a shocking video in Bali, Indonesia that went viral. Surprisingly just after China, Indonesia is the 2nd largest plastic polluter in the world producing 130,000 tons of plastic wastes everyday due to their poor recycling awareness (Lamb, 2018).

Table 1. Time it takes for garbage to decompose

\begin{tabular}{ll}
\hline Item & Time \\
\hline Glass Bottle & 1 million years \\
Monofilament fishing ling & 600 years \\
Plastic beverage bottles & 450 years \\
Disposable diapers & 450 years \\
Foamed plastic buoy & 80 years \\
Foamed plastic cup & 50 years \\
Rubber boot sole & 50 -80 years \\
Nylon Fabric & $30-40$ years \\
Plastic film container & 20 -30 years \\
Plastic bag & $10-20$ years \\
Cigarette butt & $1-5$ years \\
Plywood & $1-3$ years \\
Apple core & 2 months \\
Newspaper & 6 weeks \\
Paper towel & $2-4$ weeks \\
Leather & 50 years \\
\hline
\end{tabular}

Note: Data of Time it takes for garbage to decompose (2017), by U.S. National Park Service; Mote Marine Lab, Sarasota FL, retrieved from: bttp://storage.neic.org/event/docs/1129/bow long does it take garbage to decompose.pdf Copyright 2017 Northeast Illinois Council.

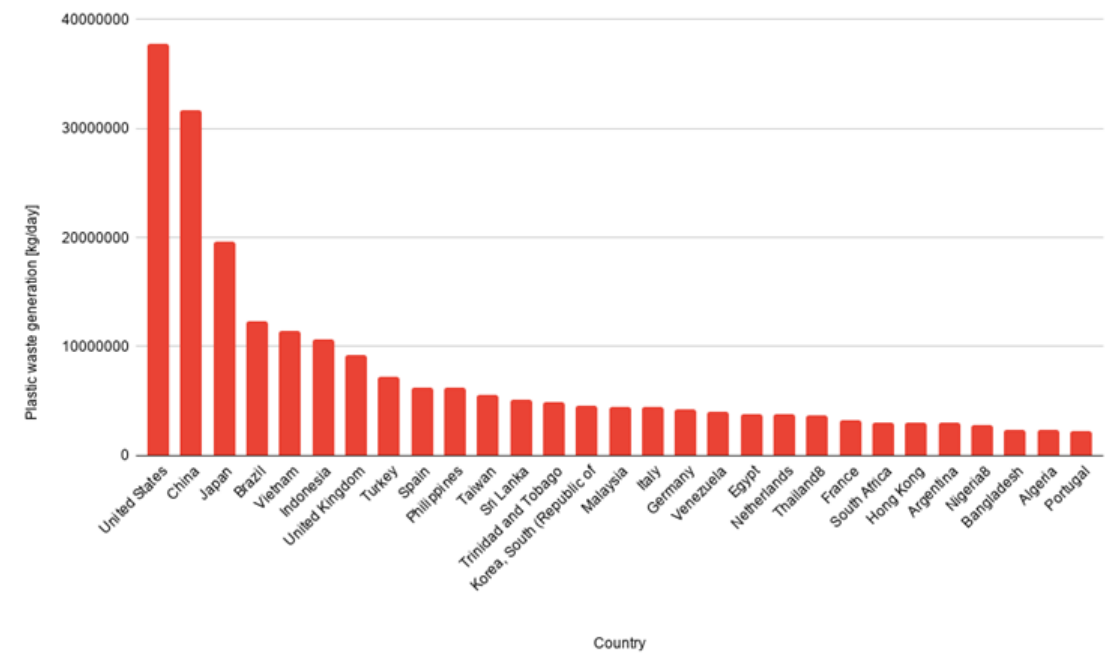

Figure 3. Plastic waste generation (Kg/Day) of top 30 countries, 2014 
In 2015 globally plastic was mostly used for packaging which was about 146 million metric tons (Jambeck et al., 2017). Still now, plastic is mostly used in the packaging sector. Nearly 360 billion Euros of turnover was recorded in 2018 by the European plastic industry, where nearly 359 million tons of plastic was produced in the same year globally (PlasticsEurope Deutschland, 2019). Research finds that human are perhaps very much exposed to micro-plastics regularly as micro-plastics have been found in human stools (United European Gastroenterology, 2018). More than $90 \%$ of all plastic ever produced has not been recycled globally (Jambeck et al., 2017).

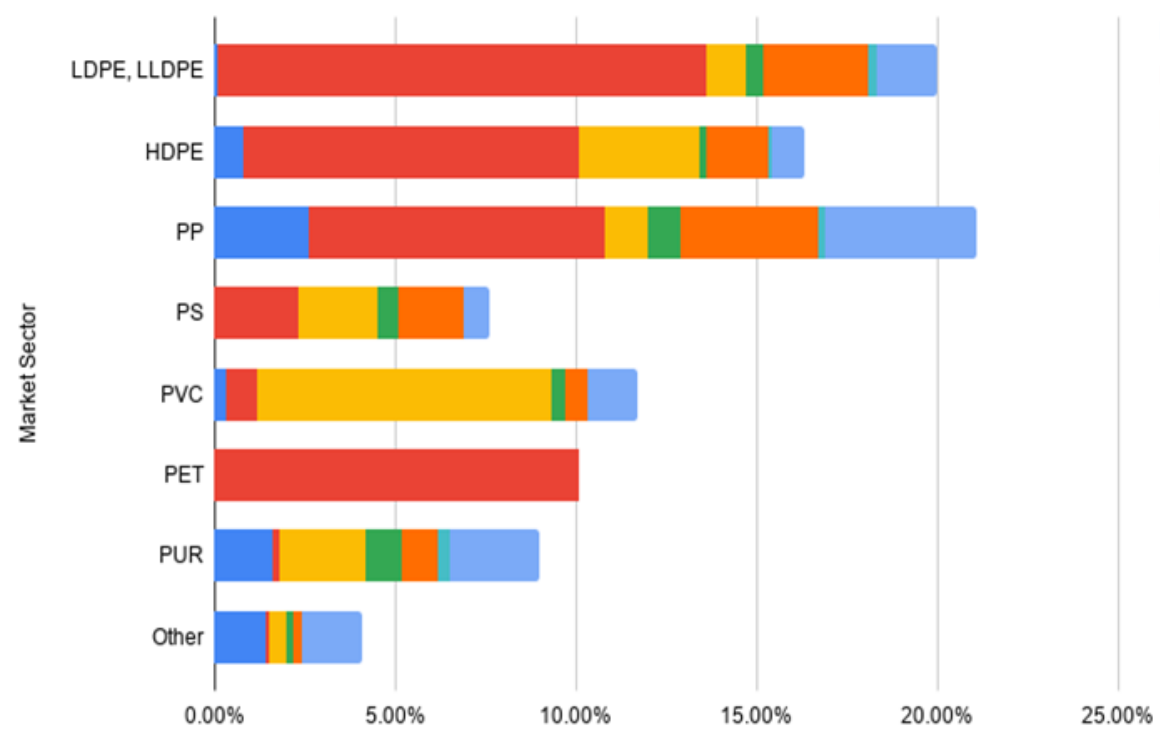

Transportation

Packaging

Building \& Construction

Electrical/Electronics

Consumer \& Institutional products

Industrial Machinery

Others

Figure 4. Types of polymer used in several sectors, calculated from data of Europe, the United States, China, and India from 2002-2014.

Note: $\mathbf{L D P E}=$ low density polyethylene, $\mathbf{L L D P E}=$ linear low density polyethylene, $\boldsymbol{H D P E}=$ High-density polyetbylene, $\boldsymbol{P P}=$ Polypropylene, $\boldsymbol{P S}=$ Polystyrene, $\boldsymbol{P V C}=$ polyvinyl chloride, $\boldsymbol{P E} \boldsymbol{T}=$ Polyethylene terephthalate, $\boldsymbol{P U} \boldsymbol{R}=$ Polyurethane

With the rising trend of the use of plastic, Bangladesh however has faced another issue regarding plastic in 2020. The global pandemic of coronavirus has increased the use of plastic as people are using a lot of single use plastic materials like gloves, masks, goggles etc. These have generated a great amount of medical waste. According to Al Jazeera, around 250 tons of medical wastes were generated by hospitals in May 2020 (Chowdhury, 2020).

\section{Concept of Sustainability and Agenda 2030}

The concept of Sustainability was first introduced at Brundland Report published in defining, sustainable development as an advancement of addressing the necessities of the present without bargaining the capacity of people in the future to address their own issues (World Commission on Environment and Development, 1987). Its aim of Agenda 21, which was later introduced in 1992 is to achieve global sustainable development. 178 Countries signed in the amendment known as Agenda 21. However, Agenda 21 had 17 goals that later paved the way for Agenda 2030, widely known as Agenda 2030 for Sustainable Development. It was signed in 2015 by 193 countries and it includes 169 targets under 17 sections also considered as 17 SDG's (United Nations, 2020). Attaining the SDG's is a major target for Bangladesh as a developing country. The 17 SDG's discuss about several factors including gender equality, quality education, life on earth etc. Jute is a major industry that can help Bangladesh in gaining an upper hand at attaining multiple SDG's at the same time. Jute, a very eco-friendly crop, has great opportunities to be explored and innovated. It can play a vital role in the following SDG's directly and indirectly- 


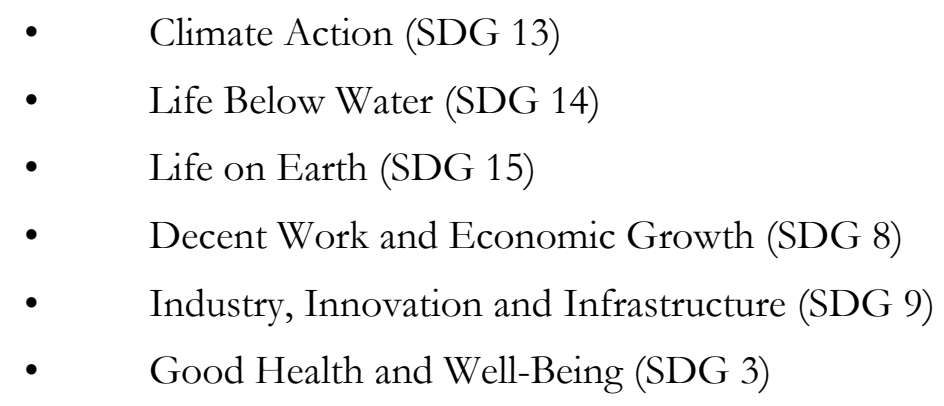

\section{Discussion: Versatility of Jute and Bangladesh's Opportunity}

Jute has great opportunities of diversification. Jute was commonly used in making ropes, threads and paper in Bangladesh. Later it was widely used for making floor mats, curtains, and several textile based products. But experts suggest, jute is not limited to these manufactured goods only. In attaining the Sustainable Development Goals mentioned in the previous section, jute is a great tool.

\section{Air Purification}

Jute requires much less land for production compared to other types of crops and it requires much less care or effort as well. It is 100\% biodegradable and has great abilities of consuming CO2. According to studies, jute can consume 15 tons of CO2 per hectare and release about 11 tons of Oxygen (Islam S. , 2013). Bangladesh is one of the most polluted countries of the world and Dhaka has been ranked as the 5th most air polluted city in the world with an air quality index (AQI) of 117 (Tribune Desk, 2020). With the high capacity of carbon consumption, jute is a vital element and resource of Bangladesh. Jute also has the ability of producing bio mass up to $98 \mathrm{~kg} /$ per hector compared to other plants that can produce only $28 \mathrm{~kg} /$ per hector (Abdullah, 2013).

\section{Biopolymer Industry}

One of the biggest challenges for the world in attaining sustainability is the use of traditional plastics and polythene. There are a number of reasons for a consumer to buy polythene - availability, price, ease of use, habit etc. People have been so much familiar with plastics and polythene that imagining a day without the use of these can be considered as a miracle. For years researchers are working to get a proper solution or a replacement for this problem. The only replacement of polythene is bioplastic and till now the most effective one in every aspect is jute based bioplastic.

In Bangladesh, the use of polythene is prohibited since 2002, but it still widely being used every day (The Daily Inqilab, 2017). Bangladeshi scientist, Mubarak Ahmed Khan, invented jute based bioplastic in the year 2017 and was named as "Sonali Bag". The concept of bioplastic or biodegradable bags is not new. An earlier version of biodegradable plastic was introduced to the world before jute based bioplastic. Starch based bioplastic is the most prominent type of bioplastic in the world currently, but yet not very successful compared to the market share of traditional plastics. It has a dominant position of $50 \%$ market share of bioplastics (Kundu, 2010). Since raw material of starch based bioplastics are widely available, producing it is not a very complex issue. But compared to traditional plastics, it has not been very effective due to a number of reasons but jute based bioplastics can be much competitive in the same aspects.

- $\quad$ Starch based polymers have high water-vapor permeability (WVP) which is a major drawback (Ribba et al., 2017). On the other hand, Sonali Bag is 1.5 times stronger than traditional plastic bags, even though it looks similar in terms of thinness (Ara, 2019).

- $\quad$ Starch based polymers face global ethical issues as the raw material is corn or potato, which is consumable. With a large number of people starving for food, using it for replacing polythene 
is a question of ethics. Again, jute is not consumable and it requires significantly less attention, less land area, less fertilizer and pesticide usage, thus it has an advantage.

- Sonali Bag, or the Jute based polymer that Bangladesh has produced is $100 \%$ biodegradable, it takes 5 hours to degrade in water and later it becomes food for the fish (Kamal, 2019).

- $\quad$ Starch based biopolymers costs about $\$ 0.82$ - \$0.98 USD/lb at optimum production (Sustainable Bioplastics Council of Maine, 2010). Jute based biopolymers will cost $\$ 0.3$ - \$0.61 USD/lb at optimum production level (The Daily Inqilab, 2017).

According to Energy and Gold Ltd. by 2030 it is forecasted that the plastic industry will have a market value of $\$ 1127$ Billion USD and bioplastics will have market value of $\$ 324$ Billion USD with a $40 \%$ market share (Pavel \& Supinit, 2018). It is also found that traditional plastic industry growth is 3\% per annum while bioplastic market is estimated to grow at a 30\% CAGR for 2013-2030 (Pavel \& Supinit, 2018). The demand for shopping bags per year is estimated to be 500 billion pieces per year (Jahan, 2019). As mentioned in Figure 4, the packaging industry is a very promising industry where traditional plastic is widely dominating the market but jute based biopolymer can play a vital role as it has great competitive advantage compared to other biopolymers.
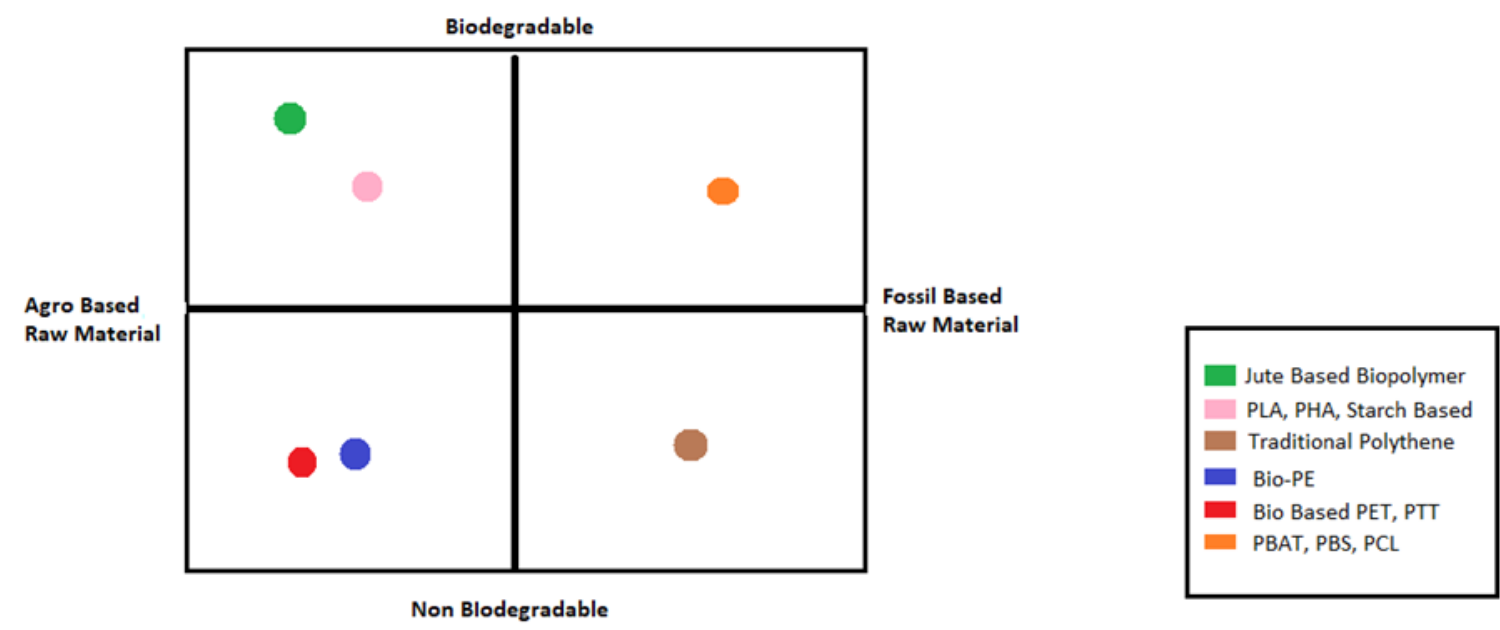

Figure 5. Positioning of Sonali Bag (Jute Based Biopolymer) compared to other forms of plastics

Note: $\boldsymbol{P L A}=$ Polylactic Acid, $\boldsymbol{P H A}=$ Polybydroxyalkonate, $\boldsymbol{B i o}-\boldsymbol{P E}=$ Bio-polythene, $\boldsymbol{P E T}=$ Polyethylene Terepththalate, $\boldsymbol{P T T}=$ Polytrimethylene Terephthalate, $\boldsymbol{P B A T}=$ Polybutylene Adipate Terephthalate, $\boldsymbol{P B S}=$ Polybutylene Succinate, $\boldsymbol{P C L}=$ Polycaprolactone

\section{Automobile Industry}

Jute is one of the major elements used now by a number of global car manufacturing brands like Marcedes Benz, Toyota, Suzuki, Hyundai and the practice started since 1990 (Ferdous \& Hossain, 2017) (Jahan, 2019). Now it is also being used in manufacturing seats, indoor panels and even bodies of the vehicle (Ferdous \& Hossain, 2017). In USA, every year 10-11 million vehicles are bought and after the usage $96 \%$ of them are processed of which $25 \%$ of them contains plastic wastes which remain as a waste (Ferdous \& Hossain, 2017). Bangladesh Auto Industries Limited (BAIL) said earlier that they would start their production of electric vehicles by the year 2020 as demand for electric vehicles is rising globally (Chakma, 2019a). The electric vehicle market in the Asia Pacific is forecasted to be USD 166 billion by 2025 with a 29\% compound annual growth 
rate (Asia Pacific Accreditation Cooperation, 2020). Nitol-Niloy Motors is has also planned to diversify their automobile sector and expand it to electric vehicles through assembling from 2020 (Chakma, 2019b). In Bangladesh, the number of cars sold each day on an average is 63 with an average growth rate of 8\% since 2012 (Byron \& Chakma, 2020). With a rising demand trend of electric vehicles \& traditional vehicles and the ability of Bangladesh in automobile industry, Jute can assist Bangladesh in producing sustainable and effective automobile components that will help in reducing cost as Bangladesh plans to produce vehicles in domestic land.

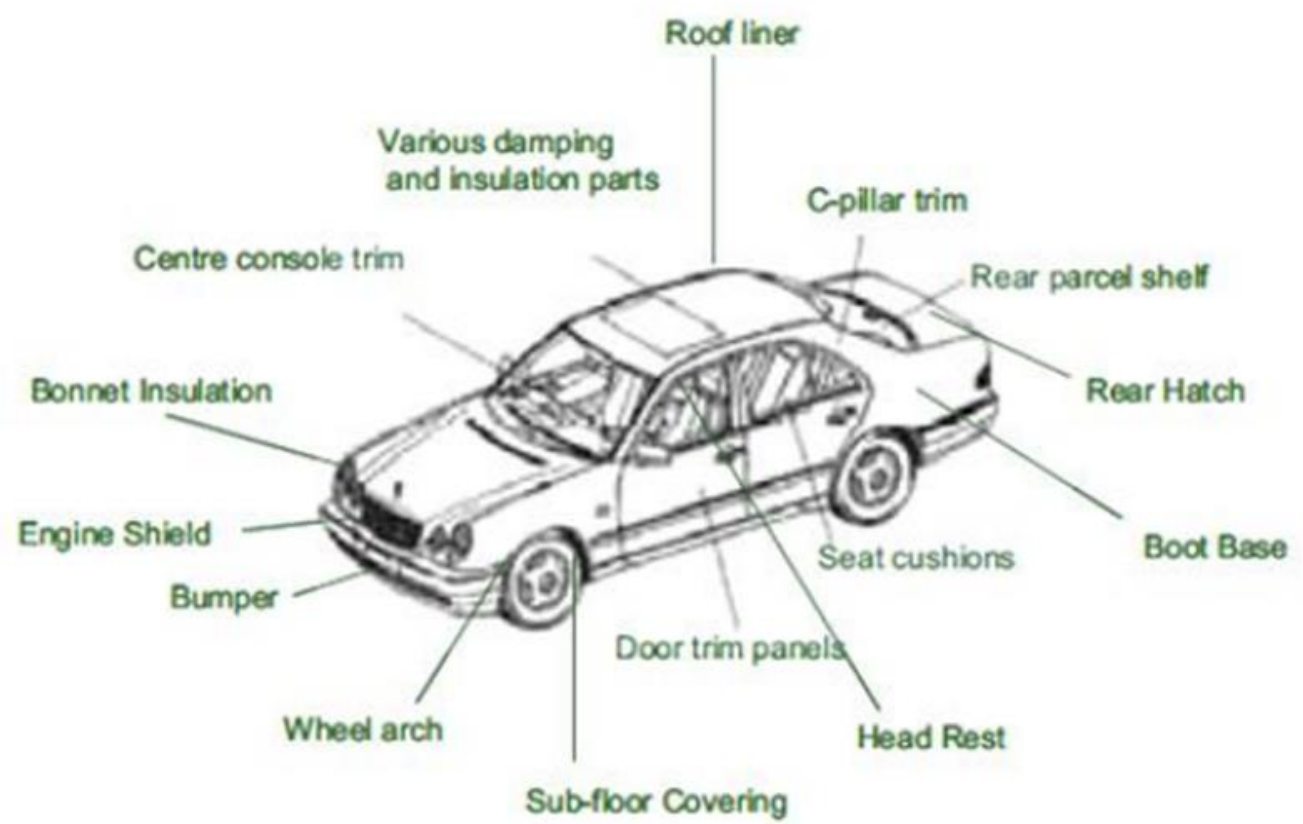

Figure 6. Jute being used in manufacturing several components of a vehicle

Note: Components on a car, made from NFC material (2017), by Suraiya Ferdous and Md Sarwar Hossain, Retrieved from: https:/ / media.neliti.com/ media/publications/262755-natural-fibre-composite-nfc-new-gateway-2c82f940.pdf copyright 2017 World Journal of Research and Review (WJRR)

\section{Construction Industry}

Bangladeshi scientist Dr. Mubarak Ahmed Khan patented a NFC (Natural Fiber Composite) in 2010 known as "Jutin" which is a roofing material, combination of jute and polyester resin, 2.5 times stronger than any traditional sheet and is rust, heat and saline proof (Ferdous \& Hossain, 2017). Using jute and plastic, jute thermoplastic sheet is manufactured which is now being used in producing housing materials like doors, windows etc (Jahan, 2019). JUTEBORG, a Swedish company founded in 2013, has been actively working with Razzaque Jute Industries Ltd (RJIL) and successfully manufactured a sustainable and cost effective cable protection pipe named "JuteSnap Split Pipe" in 2020 (JUTEBORG, 2020). The plastic pipe market is calculated to grow at a $20 \%$ annual growth with a market value worth $\$ 788$ Million USD in Bangladesh and experts claim that jute fiber reinforced granule is the most advanced and effective alternative of traditional plastic (JUTEBORG, 2020). 


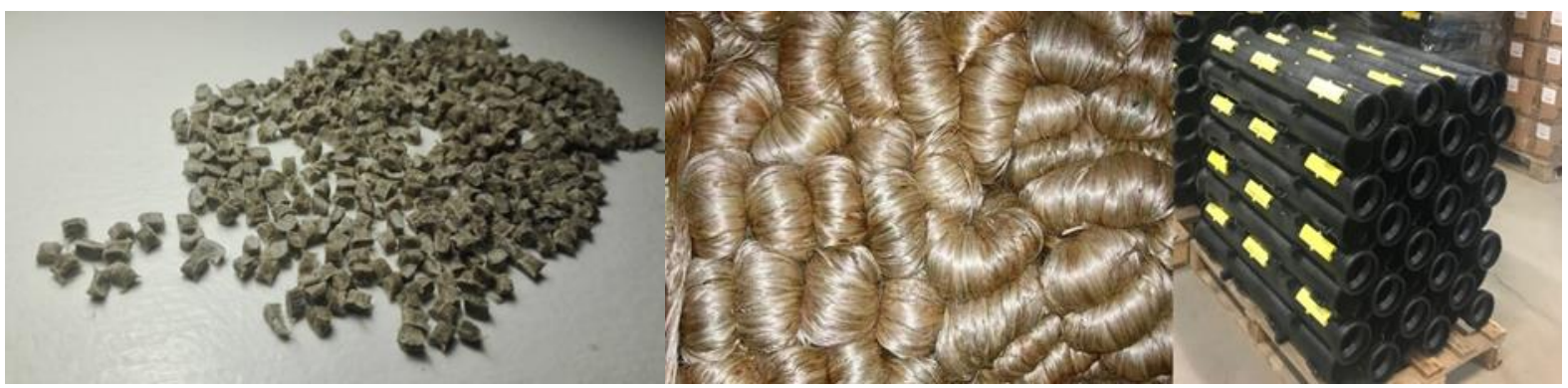

Figure 7. Jute granule and JuteSnap Split Pipe manufactured by JUTEBORG

Note: Jute Granule (Left) and Raw Jute and JuteSnap Split Pipe (Right) (2020), by JUTEBORG, Retrieved from: https://www.juteborg.se/juteborg-is-proud-of-being-awarded-eu-funding-by-innowwide/?cli_action=1597303572.3 copyright 2020 Juteborg AB

\section{Clothing and Packaging Industry}

Jute is used in producing several types of clothing that has a purpose in packaging and other usages. Some of them are- hessian cloth, canvas cloth, sacking cloth, D.W. Tarpaulin, serim cloth etc. Hessian cloths are used for packaging coffee or beans and even tobacco sheets, canvas cloth is used in mines and also protection in weather, sacking clothes are used in packaging food grains and cement, D.W. Tarpaulin is used for high scale covering, and serim cloth is used in the felt industry (Mohiuddin, 2015). As it is seen from Table 4, packaging is a major sector where jute can widely be applied. Other than bags and other packaging methods, with biopolymers Bangladesh has immense opportunity to grab the clothing and packaging market globally. Around \$1.1 billion USD worth of packaging is used RMG and Knitwear industry of Bangladesh that mostly use corrugated boxed, 3-ply and 5-ply polymer (International Trade Centre, 2009). The largest market for green packaging is USA (Faruque, 2016).

\section{Waste Export Industry}

Globally, China is the largest plastic waste importer with 110 million pounds of scrap plastic in 2018 (Staub, 2019). The big question is why China imported so much of trash in the first place since it has imposed a ban on it now, and the answer is to employ people and produce cheaper plastic based products. China is the largest manufacturer of plastic based products and it is also known to everyone that it has a large labor force. Since recycling plastic became costlier than to export plastic to China, countries around the world chose to export the plastic wastes to China and China used this opportunity to earn foreign currency and create employment of 3 to 5 million Chinese people (Mak, 2018). Due to the import ban of waste plastics by China to US, US is now facing a great deal of tension as they are the largest plastic waste exporter of the world. The key player here can be jute based biopolymer which can at least reduce the packaging wastes at a cost beneficial way for the North American market. It is also applied for the European market as well. In 2016, China imported 7.38 million metric tons of plastic waste from 43 different countries where the global export was 14.1 million metric tons and an 817\% growth since 1993 (Jambeck et al., 2016). Undoubtedly it can be said that the ban will generate a big amount of plastic waste unrecycled which is a big natural threat. 


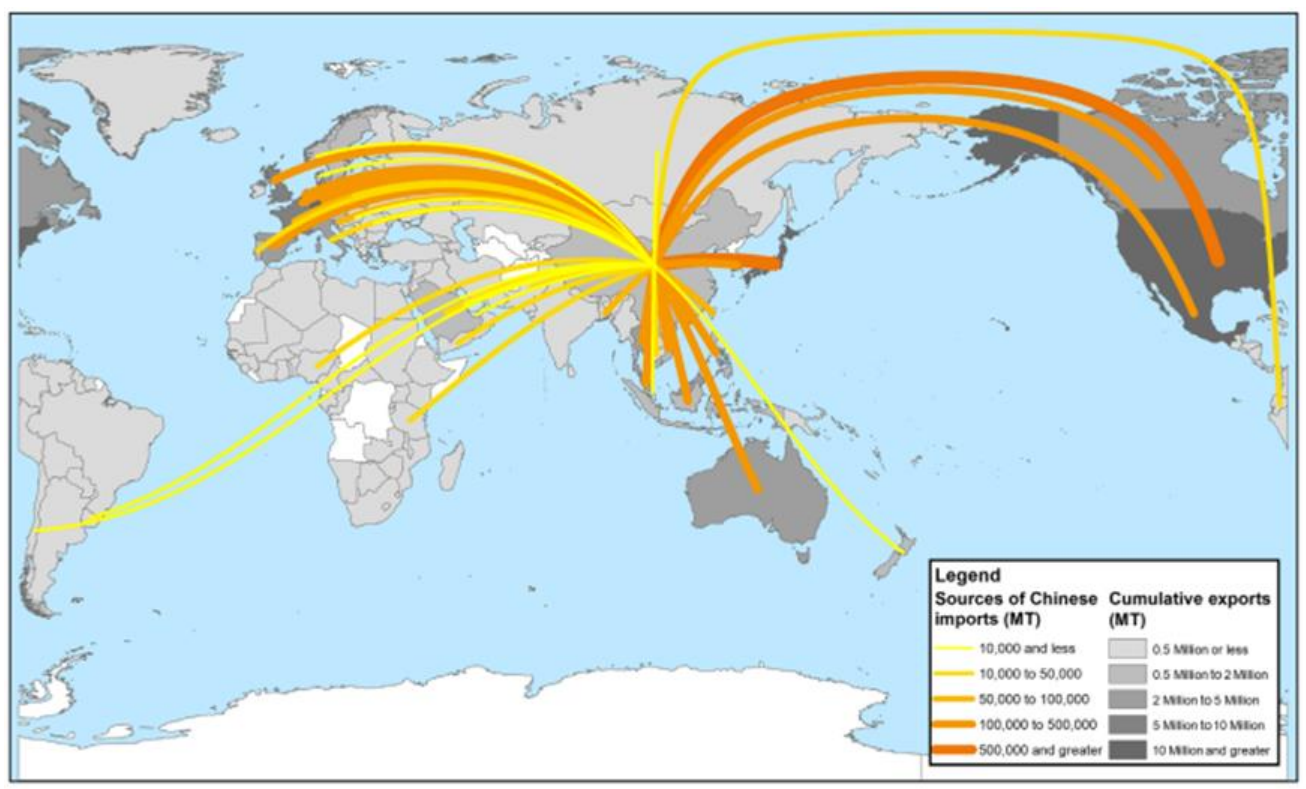

Figure 8. Sources of plastic waste imports into China in 2016 and cumulative plastic waste export tonnage (in million MT) in 1988-2016

Note: Sources of plastic waste imports into China in 2016 and cumulative plastic waste export tonnage (in million MT) in 1988-2016 (2016), by Amy L. Brooks, Shunli Wang and Jenna R. Jambeck, Retrieved from:

https:/ / advances.sciencemag.org/content/4/6/eaat0131. full copyright 2018 American Association for the Advancement of Science $(A A A S)$.

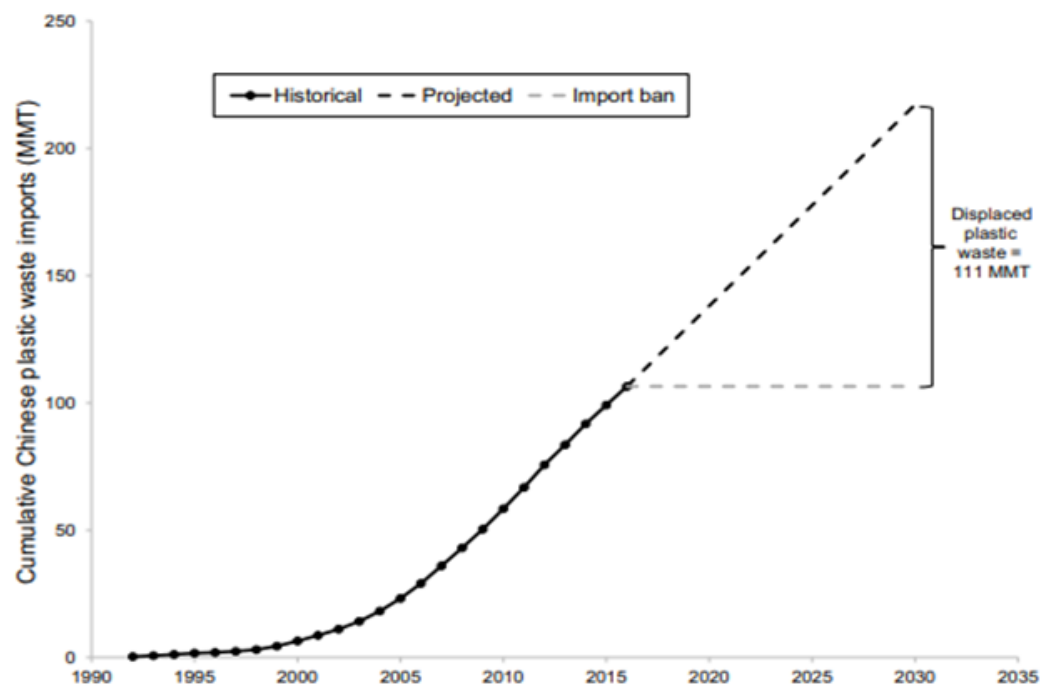

Figure 9. Estimated mass of global displaced plastic waste due to the new Chinese import ban based on cumulative imports of PE, PS, PVC, and other plastics into China

Note: Estimated mass of global displaced plastic waste due to the new Chinese import ban based on cumulative imports of PE, PS, PVC, and other plastics into China (2016), by Amy L. Brooks, Shunli Wang and Jenna R. Jambeck, Retrieved from:

bttps:/ / advances.sciencemag.org/content/4/6/eaat0131.full copyright 2018 American Association for the Advancement of Science (AAAS).

\section{Textile, Clothing, and Viscose Industry}

The textile and clothing industry can be highly benefitted by jute through blended threads. The demand of natural fiber threads has seen an upward trend that has opened up wide opportunities for a strong fiber like 
jute. If jute is mixed with cotton, the blended fiber can be used to manufacture jeans for denim which is cost beneficial as it will cost only 1/3 compared to if it was made of 100\% cotton (Kabir et al., 2019). The blended (50:50) jute cotton fabric has higher fabric strength, better dying performance, reflectance and color strength that can be an effective replacement of 100\% cotton use (Ullah et al., 2016). Bangladesh imported about 8.2 million bales of cotton in 2018 (Siddiqui, 2020). Every year, Bangladesh's import of viscose is increasing. Viscose is a type of artificial fiber that is widely used in the textile and clothing industry. Bangladesh imported viscose of 18,115 tons in 2014 that has increased up to 40, 278 tons in 2018 and Bangladesh spends about \$3.5 billion USD in importing cotton each year (Munni, 2019b). Though viscose is mainly produced from wood pulp, it can also be produced from jute (Kabir et al., 2019). With successful implementation, jute viscose can be produced up to 20,000 tons each year that will reduce the import of cotton to only 20,000 bales per annum (MP, 2018). Only 30\% cellulose can be collected from wood through a 4-5 year old tree while only 3-4 months old jute plant gives 60-70\% cellulose (MP, 2018). Jute cellulose can be used to make several products like powder, medicine peel etc. and it is calculated that the powder will cost only USD \$25-27/kg using jute, while USD $\$ 1800 / \mathrm{kg}$ from wood (MP, 2018). It is clearly understandable that with proper application of jute in textile and viscose industry, import of cotton can be drastically reduced and innovation in pharmaceuticals and several other sectors can take place.

\section{Charcoal and Cosmetics Industry}

Jute stick has a significant potential for global exports. The ash produced after jute stick burning is a significant element in the cosmetics and charcoal industry, which is used in making tooth cleaner, smell remover, facewash (Kabir et al., 2019). The ash of jute is also used in making the dark ink of electronic printers known as cartridges and also used as carbon powder in dry-cell batteries (Kabir et al., 2019). Jute charcoal industry is worth $\$ 200$ million USD per annum in the international market, if only half of the production is utilized and can reach up to \$3-3.5 Billion USD (Kabir et al., 2019).

\section{Organic Tea Industry}

With the rising trend of health consciousness, Bangladeshi scientists have claimed to produce jute leaf tea that contains $30 \%$ more calories than spinach, rich with iron, vitamins, calcium, carbohydrates, protein etc (Molla, 2016). In the fiscal year 2018-19, nearly 2.5 metric tons of jute leaf tea was exported to Germany (Bangladesh Sangbad Sangstha , 2019). There is a global demand for organic tea as people are becoming more health conscious and jute leaf tea can be a major player in this market.

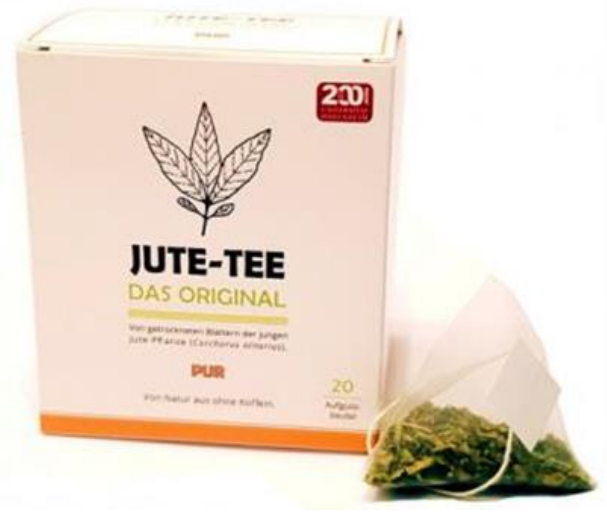

Figure 10. Jute tea that is exported to Germany

Note: Jute-Tee Packet (2019), by Prothom Alo, retrieved from: httss:/ / en.prothomalo.com/ bangladesh/Jute-Tee-Bangladesh-beverage-inGerman-cups 


\section{Geo-Textile Industry}

Geo-textile is the most flexible and practical ground alteration materials and it is an exceptional sort of specialized material which is utilized in establishment, soil, rock, earth, or some other geotechnical designing material in human made venture, structure or framework (Textile Today, 2020). Jute geo-textile can be applied in multiple sectors including civil engineering, hydraulic engineering, soil stabilization etc. (Kabir et al., 2019). From the concept of sustainability, jute based geo-textile has a lot of competitive advantages against synthetic geo-textile like biodegradability, photo-degradability, absence of metal substance, no warming effect, fertilizer effect, simple technology and no pollution (Textile Today, 2020). According to a report, at a CAGR of 10.2\%, the global geo-textile industry will reach USD $\$ 9.2$ billion by the year 2022 (Singh, 2019).

\section{Pulp and Paper Industry}

Bangladesh produces the best quality of jute in the world and jute is a significant raw material for paper and pulp industry. Bangladesh produces around 33\% of the global jute that can open up to USD \$600 million worth of pulp (The Financial Express, 2018). Since pulp collected from wood is costly, jute is an effective alternative to meet the local demand and also open up to global exports.

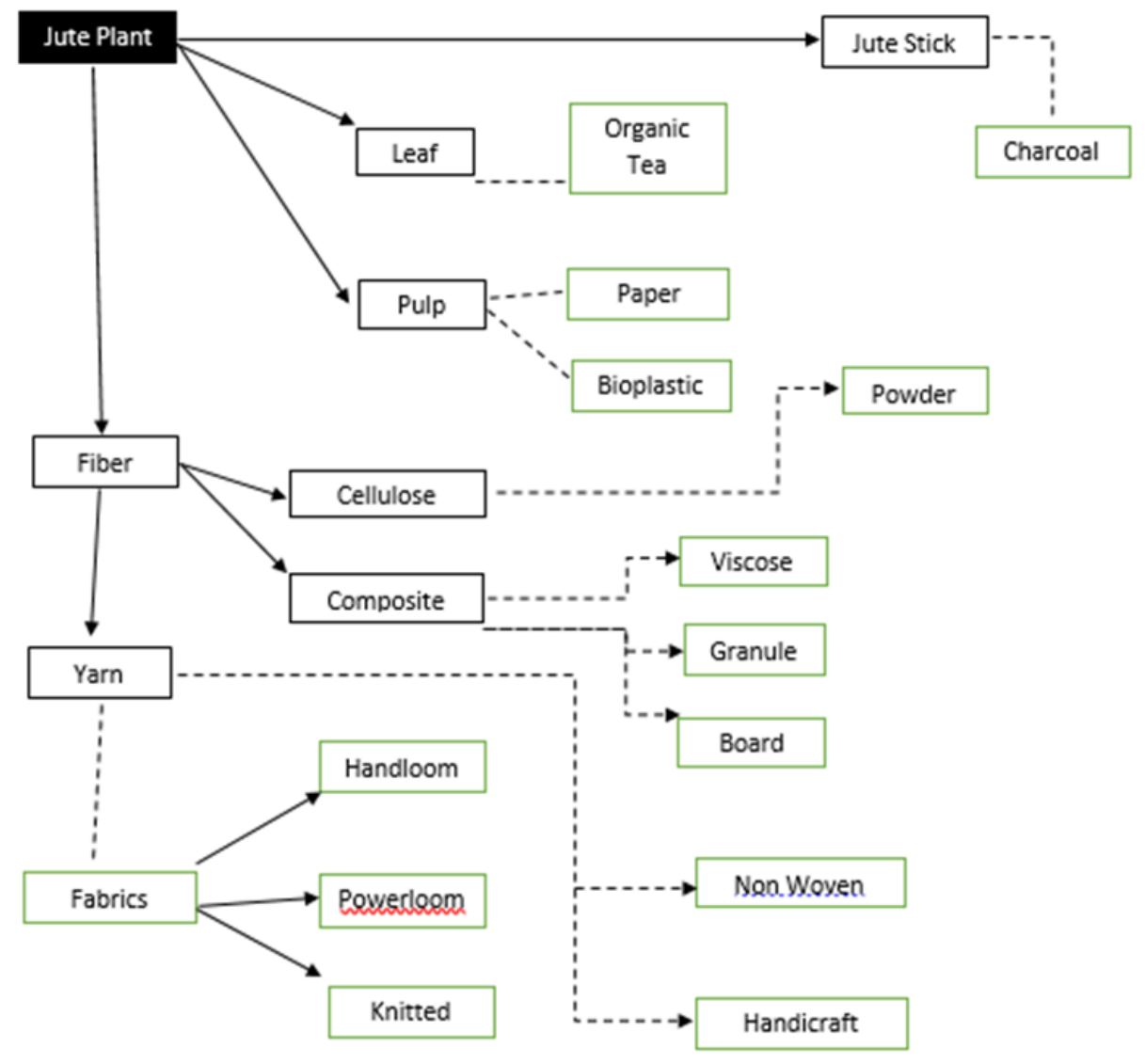

Figure 11. Diversified products from Jute

\section{Conclusion}

When it comes to ecological sustainability, green products is undoubtedly the only option. Jute is such a valuable resource for the world and Bangladesh that it alone can have great impact in sustainable development. The diversification ability of jute clearly identifies the future potential of the market for Bangladesh. But the 
highlighting part is, not only every single element of jute can be used, but also it is highly eco-friendly and can be used to make eco-friendly products for a better future.

\section{Practical Implications}

As discussed earlier, jute can be diversified in a number of industries that can be dramatically financially beneficial, especially for jute growing countries like Bangladesh and India. Initially, the production of jute is decreasing for a number of reasons. The most vital cause is that the producers not getting enough profit from the crop, unnecessary intermediaries increasing the cost of final product and, poor lead time management.

However, the industries discussed above are all existing in Bangladesh, except the automobile industry. But within 2025, Bangladesh plans to produce automobile domestically as well. Thus the similar technology using jute can be used to minimize cost. Bangladesh also has the technology of producing biopolymer as Dr. M.A. Khan has already successfully produced it at a scientific production level. With help of foreign and government investment this can play as a vital element in solving the global single use plastic problem. As for the other industries, similar approach is applied.

As a number of industries are using several elements of jute, so working side by side, jute can be used completely by different industries. To elaborate the fact, the figure below can explain it properly.

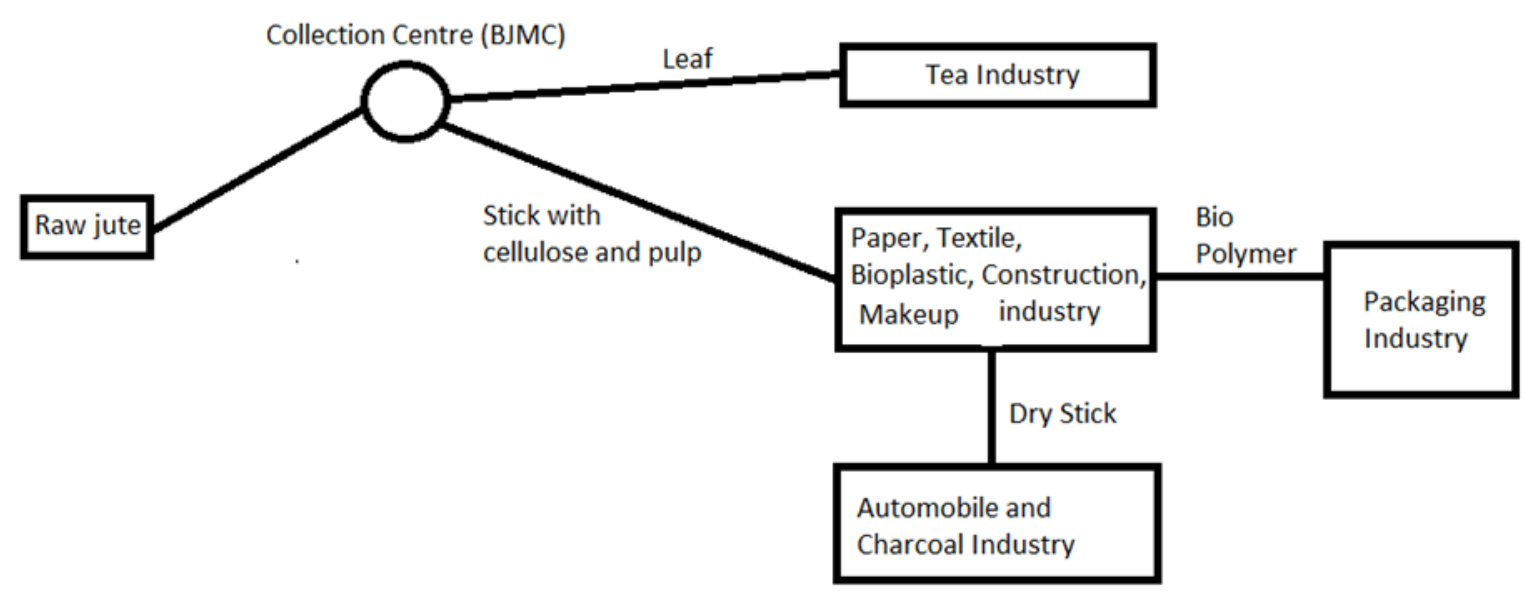

Figure 12. Distribution of jute in several industries

In Bangladesh, BJMC can play the center role for jute's distribution. All raw jutes can be collected and distributed via BJMC. The leaf can be sent directly to the organic tea industry while the stick with cellulose and pulp in it can be sent to those industries who require it. After pulp and cellulose is collected, the leftover dry stick is no longer required by those industries, thus it can be sent to Automobile and Charcoal industry as it is the required material. The final product from bioplastic industry can be sent to packaging industry for further applications.

The process discussed is a long term plan, but if applied it can bring a greener future for Bangladesh. The author points out that, not all the industries can be introduced at the same time as the production of jute is not up to that level that it can meet all the industry's demand at the same time. But Bangladesh has great opportunities to improve production level to meet the demand. Arguing on this valid point, the author highlights some facts that can make this application realistic.

\section{Private Investment and FDI}

The jute sector of Bangladesh lacks private investment from big companies and also there is no foreign direct investment (FDI). In the earlier times, when Bangladesh faced severe issues regarding lack of poultry, the 
government gave incentives to private firms for investing in poultry. The strategy was widely successful that lead to the introduction of BRAC poultry, Kazi Firms etc. The author suggests, similar approach can be taken by the government to amplify production of jute. FDI can also improve the production level dramatically as many industries require a large capital investment for operational purpose.

\section{Investment in Research}

More investment in the research of jute can be successful in improving production of jute. Bangladesh have been successful in making several plants which were seasonal plants earlier, making them all year producible. Further research can also help in making jute producible in foreign grounds as well to boost up production.

\section{Effective Supply Chain}

As mentioned earlier, the supply chain of jute is ineffective that leads to producer dissatisfaction that has lead the decrease in jute production. The producers are the heart of every industry. Thus making an effective supply chain can improve the lead time and also provide better earnings for the producers that will encourage them to produce jute in a larger scale.

Funding: This research received no specific grant from any funding agency, commercial or not-for-profit sectors.

Conflicts of Interest: The authors declare no conflict of interest.

\section{References}

Abdullah, D. A. (2013). Ecological and economic attributes of Jute and Natural fibre for sustainable Eco-Management. Dhaka: Primeasia University.

Al Jazeera. (2008, December 10). Bangladesh jute industry in decline. Retrieved from Al Jazeera: https://www.aljazeera.com/news/asia/2008/12/2008121035022494523.html

Ara, A. (2019, October 9). Sonali Bag gets ready for commercial production. Retrieved from The Financial Express: https:/ /www.thefinancialexpress.com.bd/trade/sonali-bag-gets-ready-for-commercial-production1571458150\#: :text=According $\% 20$ to $\% 20$ the $\% 20 \mathrm{BJMC} \% 2 \mathrm{C} \% 20$ Sonali,polythene $\% 20$ takes $\% 20$ several $\% 20 \mathrm{~h}$ undred $\% 20$ years.

Asia Pacific Accreditation Cooperation. (2020, February). APAC Electric Vehicle Market. Retrieved from market data forecast: https://www.marketdataforecast.com/market-reports/apac-electric-vehicle-market

Bangladesh Sangbad Sangstha . (2019, September 9). Bangladesh to export 5 metric tons tea produced from jute leaves this year. Retrieved from The Daily Sun: https://www.daily-sun.com/post/422234/Bangladesh-to-export-5metric-tons-tea-produced-from-jute-leaves-this-year

Banglapedia. (2015, February 9). Jute. Retrieved from Banglapedia: http://en.banglapedia.org/index.php?title=Jute

Bay, B. (2020, July 4). End of state-owned jute mills: why close when you can reform? Retrieved from The Daily Star : https:/ /www.thedailystar.net/opinion/magic-madness/news/end-state-owned-jute-mills-why-close-when-youcan-reform-

1924661\#: :text=According\%20to\%20data\%20from\%20the,months\%20of\%20FY\%202019\%2D2020.\&text $=\mathrm{In} \% 20$ the $\% 20$ process $\% 2 \mathrm{C} \% 20$ the $\% 20$ jute, in $\% 20$ Bangladesh's $\% 2$

BGMEA. (2020, June 13). Tradeinformation. Retrieved from BGMEA: https://www.bgmea.com.bd/home/pages/TradeInformation

Boucher, J., \& Friot, D. (2017). Primary Microplastics in the Ocean: A Global Evaluation of Sources. Gland, Switzerland: IUCN. doi:dx.doi.org/10.2305/IUCN.CH.2017.01.en

Brooks, A. L., Wang, S., \& Jambeck, J. R. (2016, June 20). The Chinese import ban and its impact on global. doi:10.1126/sciadv.aat0131

Byron, R. K., \& Chakma, J. (2020, September 1). Cars 'made in Bangladesh' on the way. Retrieved from The Daily Star: https://www.thedailystar.net/business/news/cars-made-bangladesh-the-way-1953853 
Chakma, J. (2019, July 24). Local firm to set up $\$ 200 \mathrm{~m}$ plant to make electric vehicle. Retrieved from The Daily Star: https://www.thedailystar.net/business/news/local-firm-set-200m-plant-make-electric-vehicle-1776208

Chakma, J. (2019, January 24). Locally assembled electric cars to hit streets soon. Retrieved from The Daily Star: https://www.thedailystar.net/business/news/locally-assembled-electric-cars-hit-streets-soon-1692118

Chowdhury, T. (2020, June 2). Can Bangladesh deal with mountains of COVID-19 medical waste? Retrieved from Al Jazeera: https://www.aljazeera.com/news/2020/06/bangladesh-deal-mountains-covid-19-medical-waste200602084636302.html

Faruque, P. D. (2016). FUTURE TRENDS FOR ENVIRONMENTAL SUSTAINABILITY OF GARMENTS ACCESSORIES \& PACKAGING INDUSTRY IN BANGLADESH. Dhaka: Bangladesh Garments Accessories \& Packaging Manufacturers\& Exporters Association. Retrieved from http://www.bgapmea.org/index.php/home/study_report/

Ferdous, S., \& Hossain, M. S. (2017, September). Natural Fibre Composite (NFC): New Gateway for Jute, Kenaf and Allied Fibres in Automobiles and Infrastructure Sector. World Journal of Research and Review (WJRR), 5(3), 35-42. Retrieved from https://media.neliti.com/media/publications/262755-natural-fibre-composite-nfc-newgateway-2c82f940.pdf

Geyer, R., Jambeck, J. R., \& Law, K. L. (2017, July 19). Production, use, and fate of all plastics ever made. Science Advances, 3(7), 12. doi:10.1126/sciadv.1700782

Guern, C. L. (2019, November). WHEN THE MERMAIDS CRY: THE GREAT PLASTIC TIDE. Retrieved from Coastal Care: https://plastic-pollution.org/

Harmachi, A. R. (2020, May 10). Jute joy amid coronavirus cloud over Bangladesh exports. Retrieved from bdnews24.com: https://bdnews24.com/business/2020/05/10/jute-joy-amid-coronavirus-cloud-overbangladesh-exports

Indexbox. (2020, January 17). World - Jute And Jute-Like Fibers - Market Analysis, Forecast, Size, Trends and Insights. Retrieved from indexbox.io: https://www.indexbox.io/store/world-jute-and-jute-like-fibers-market-analysisforecast-size-trends-and-insights/

International Trade Centre. (2009). Packaging Industry Audit Bangladesh. Geneva: International Trade Centre (ITC). Retrieved from http://www.bgapmea.org/index.php/home/study_report/10

Ishaque, M. (2019, September 9). RMG Industry Outlook 2019. Retrieved from Textile Focus: http://textilefocus.com/rmg-industry-outlook2019/\#: :text=Export $\% 20$ Status,growing $\% 20$ by $\% 2010.55 \% 25 \% 20$ in $\% 20 \mathrm{FY} 19$.

Islam, R. (2018, March 7). 'Jute is our golden future'. Retrieved from Dhaka Tribune: https://www.dhakatribune.com/business/economy/2018/03/07/growth-jute-golden-future/

Islam, S. (2013, January 5). Jute is golden also for environment. Retrieved from The Daily Star: https://www.thedailystar.net/news-detail-

263840\#: : text=Studies $\% 20$ reveal $\% 20$ that $\% 20$ the $\% 20$ C02,season $\% 20$ (about $\% 20100 \% 20$ days).

Jahan, A. (2019). The environmental and economic prospects of jute with a connection to social factors for achieving Sustainable Development. Uppsala: Department of Earth Sciences, Uppsala University. Retrieved from http://uu.diva-portal.org/smash/get/diva2:1328785/FULLTEXT01.pdf

JUTEBORG. (2020, August 12). Juteborg is proud of being awarded EU funding by INNOWWIDE. Retrieved from JUTEBORG: https://www.juteborg.se/juteborg-is-proud-of-being-awarded-eu-funding-byinnowwide/?cli_action $=1597303572.3$

Kabir, D. M., Razzaque, D. M., \& Rabi, M. R. (2019). Reviving Exports of Jute Products from Bangladesh. Dhaka: Bangladesh Enterprise Institute. Retrieved from https://bei-bd.org/wp-content/uploads/2020/06/7.RevivingExports-of-Jute-Products-from-Bangladesh.pdf

Kamal, M. Z. (2019, January 21). Bangladesh has the answer to polythene menace. Retrieved from United News of Bangladesh: https://unb.com.bd/category/Special/bangladesh-has-the-answer-to-polythenemenace/10981\#: : :text $=$ The $\% 20 \mathrm{bag} \% 2 \mathrm{C} \% 20$ named $\% 20$ 'Sonali',conventional $\% 20$ polythene $\% 20 \mathrm{bags} \% 2 \mathrm{C} \% 20$ he $\% 20$ says.\&text $=$ It $\% 20$ takes $\% 20$ the $\% 20 \mathrm{bag} \% 20$ five, fish $\% 20$ because $\% 20$ it $\% 20$ has $\% 20$ cellulose.

Kundu, D. A. (2010, September 19). Types of Bioplastic. Retrieved from InnovativeIndustry.net: http://www.innovativeindustry.net/types-of-bioplastic

Lamb, K. (2018, March 6). 'Plastic, plastic, plastic': British diver films sea of rubbish off Bali. Retrieved from The Guardian: https://www.theguardian.com/world/2018/mar/06/plastic-british-diver-films-sea-rubbish-baliindonesia 
Mak, A. (2018, June 21). Why Does Half of the World's Used Plastic End Up in China? Retrieved from Slate: https://slate.com/technology/2018/06/why-china-import-half-world-used-plastic.html

Mohiuddin, M. (2015, February). Green Marketing Of Jute and Jute Products: A Study on Bangladesh. IOSR Journal of Business and Management (IOSR-JBM), 17(1), 52-57. doi:10.9790/487X-17215257

Molla, M. A.-M. (2016, November 22). Care for herbal drink from jute? Retrieved from The Daily Star: https://www.thedailystar.net/frontpage/care-herbal-drink-jute-1318603

Moniruzzaman, D. M. (2010). Long Run Relationship between Export and Import of Bangladesh: Growth Trend, Cointegration and Casuality Analysis. Retrieved from https://bea-bd.org/site/images/pdf/076.pdf

MP, M. A. (2018, August 12). Huge domestic and global demand for jute viscose fiber shows a great prospect to produce it in Bangladesh where the high-quality raw material is available at low cost. (T. Today, Interviewer) Textile Today . Retrieved from https://www.textiletoday.com.bd/jute-viscose-project-will-change-historybangladeshs-jute-

industry/\#: :text=After $\% 20$ the $\% 20$ implementation $\% 20$ of $\% 20$ the,than $\% 20200 \% 2$ C000\%20bells $\% 20$ each $\% 20$ year.

Munni, M. (2019, November 27). Artificial fibre import doubles in five years. Retrieved from The Financial Express: https://thefinancialexpress.com.bd/trade/artificial-fibre-import-doubles-in-five-years-

1574831151\#: :text $=$ The $\% 20$ import $\% 20$ of $\% 20$ viscose $\% 20$ staple,only $\% 2018 \% 2$ C $115 \% 20$ tonnes $\% 20$ in $\% 2020$ 14.\&text $=\mathrm{In} \% 20$ fiscal $\% 202018 \% 2 \mathrm{D} 19 \% 2 \mathrm{C} \% 20$ Bangladesh,3.5\%20billion $\% 20 \mathrm{in} \% 20 \mathrm{importin}$

Munni, M. (2020, June 2). RMG exports drop 19pc in FY'20. Retrieved from The Financial Express: https:/ / thefinancialexpress.com.bd/economy/rmg-exports-drop-19pc-in-fy20-1593660880

Ovi, I. H. (2020, August 5). Bangladesh's share in global clothing exports rises to 6.8\%. Retrieved from Dhaka Tribune: https://www.dhakatribune.com/business/2020/08/05/rmg-global-market-share-bangladesh-still-lags-behindvietnam\#: :text=According $\% 20$ to $\% 20$ the $\% 20$ World $\% 20$ Trade,from $\% 20 \% 24421 \% 20$ billion $\% 20 \mathrm{in} \% 202018$.

Pavel, S., \& Supinit, V. (2018). Bangladesh Invented Bioplastic Jute Poly Bag and International Market Potentials. In S. Pavel, H. J. Hejase, A. J. Hejase, H. T. Assi, H. C. Chalak, \& S. N. Wamitu, Advances in Business and Management (pp. 95-121). Irvine, California, USA: Scientific Research Publishing. Retrieved from https://www.researchgate.net/publication/329075034_Advances_in_Business_and_Management

PlasticsEurope Deutschland. (2019). Plastics - the Facts 2019 : An analysis of European plastics production, demand and waste data. Brussels, Belgium: PlasticsEurope. Retrieved from https:/ /www.plasticseurope.org/application/files/9715/7129/9584/FINAL_web_version_Plastics_the_facts2 019_14102019.pdf

Ribba, L., Garcia, N. L., D'Accorso, N., \& Goyanes, S. (2017, December). Disadvantages of Starch-Based Materials, Feasible Alternatives in Order to Overcome These Limitations. doi:10.1016/B978-0-12-809439-6.00003-0

Siddiqui, M. (2020, January 19). Cotton import from US: Revoking the provision of double fumigation. Retrieved from The Financial Express: https://thefinancialexpress.com.bd/views/cotton-import-from-us-revoking-theprovision-of-double-fumigation1579446165\#: :text=BTMA $\% 20$ data $\% 20$ show $\% 2$ C $\% 20$ Bangladesh $\% 20$ in,and $\% 20$ the $\% 20$ rest $\% 2$ C $\% 209.65 \%$ 20per

Singh, S. (2019, July 25). Geotextile Market worth $\$ 9.4$ billion by 2022. Retrieved from Markets and Markets: https://www.marketsandmarkets.com/PressReleases/geotextiles.asp

SME Foundation. (2015). MARKET PROFILE - Jute Bags and Sacks. Dhaka: SME Foundation. Retrieved from http://www.smef.org.bd/v2/smef_download/market_profile/5_Market_Profile_Jute_bags_sacks.pdf

Staub, C. (2019, January 29). China: Plastic imports down 99 percent, paper down a third. Retrieved from Resource Recylcing: https://resource-recycling.com/recycling/2019/01/29/china-plastic-imports-down-99-percentpaper-down-a-

third/\#: :text=Chinese $\% 20$ companies $\% 20$ imported $\% 20110 \% 20$ million,country $\% 20$ brought $\% 20$ in $\% 20$ during $\% 202017$.

Sustainable Bioplastics Council of Maine. (2010). The Business Case for Commercial Production of Bioplastics in Maine. Maine: CONFIDENTIAL. Retrieved from https://www.ourhealthyfuture.org/sites/default/files/pdfs/the_business_case_for_commercial_production_o f_bioplastics_in_maine_final.pdf

Textile Today. (2020, September 1). Jute geo-textile \& its prospect in Bangladesh. Retrieved from Textile Today: https://www.textiletoday.com.bd/jute-geo-textile-its-prospect-in- 
bangladesh/\#: : text $=$ Geo $\% 2$ Dtextiles $\% 20$ are $\% 20$ the $\% 20$ most, made $\% 20$ project $\% 2 \mathrm{C} \% 20$ structure $\% 20$ or $\% 20$ system.

The Daily Inqilab. (2017, October 3). পাট থেকে পলিথিন ব্যাগ. Retrieved from The Daily Inquilab: https://www.dailyinqilab.com/article/98070/\%E0\%A6\%AA\%E0\%A6\%BE\%E0\%A6\%9F$\% \mathrm{E} 0 \% \mathrm{~A} 6 \% \mathrm{~A} 5 \% \mathrm{E} 0 \% \mathrm{~A} 7 \% 87 \% \mathrm{E} 0 \% \mathrm{~A} 6 \% 95 \% \mathrm{E} 0 \% \mathrm{~A} 7 \% 87-$ $\% \mathrm{E} 0 \% \mathrm{~A} 6 \% \mathrm{AA} \% \mathrm{E} 0 \% \mathrm{~A} 6 \% \mathrm{~B} 2 \% \mathrm{E} 0 \% \mathrm{~A} 6 \% \mathrm{BF} \% \mathrm{E} 0 \% \mathrm{~A} 6 \% \mathrm{~A} 5 \% \mathrm{E} 0 \% \mathrm{~A} 6 \% \mathrm{BF} \% \mathrm{E} 0 \% \mathrm{~A} 6 \% \mathrm{~A} 8-$ $\% \mathrm{E} 0 \% \mathrm{~A} 6 \% \mathrm{AC} \% \mathrm{E} 0 \% \mathrm{~A} 7 \% 8 \mathrm{D} \% \mathrm{E} 0 \% \mathrm{~A} 6 \% \mathrm{AF} \% \mathrm{E} 0 \% \mathrm{~A} 6 \% \mathrm{BE} \% \mathrm{E} 0 \% \mathrm{~A} 6 \% 97-$

?_cf_chl_jschl_tk__=328bd1745f3d8983f0a3e713a

The Financial Express. (2018, May 11). Jute pulp paper. Retrieved from The Financial Express: https://thefinancialexpress.com.bd/editorial/jute-pulp-paper

Tribune Desk. (2020, June 17). Dhaka ranks 5th worst in Air Quality Index. Retrieved from Dhaka Tribune: https://www.dhakatribune.com/bangladesh/dhaka/2020/06/17/dhaka-ranks-5th-worst-in-air-quality-index-2

Ullah, A. A., Foisal, A., \& Nahar, N. (2016, December). Study on the Characteristics of Jute-Cotton Blended Fabrics. SEU Journal of Science and Engineering, 10(2), 12-16. Retrieved from https://www.researchgate.net/publication/320584603_Study_on_the_Characteristics_of_JuteCotton_Blended_Fabrics

UN Environment. (2018). Our planet is drowning in plastic pollution. Retrieved from UN Environment: https://www.unenvironment.org/interactive/beat-plastic-

pollution/\#: :text $=$ Around $\% 20$ the $\% 20$ world $\% 2 C \% 20$ one $\% 20$ million,once $\% 20 \%$ E2\%80\%94\%20and $\% 20$ the n\%20thrown $\% 20$ away.

United European Gastroenterology. (2018, October 23). UEG Week: Microplastics discovered in human stools across the globe in first study of its kind. Retrieved from UEG: https://www.ueg.eu/press/releases/ueg-pressrelease/article/ueg-week-microplastics-discovered-in-human-stools-across-the-globe-in-first-study-of-its-kind

United Nations. (2020, September 27). Sustainable Development Goals Officially Adopted by 193 Countries. Retrieved from United Nations in China:

http://www.un.org.cn/info/6/620.html\#: :text=Countries\%20officially $\% 20$ adopted $\% 20$ the $\% 20$ historic,Susta inable $\% 20$ Development $\% 20$ Goals $\% 20$ (SDGs).

World Commission on Environment and Development. (1987). Our Common Future. Oxford: Oxford Unversity Press. Retrieved from https://sustainabledevelopment.un.org/content/documents/5987our-commonfuture.pdf 